\title{
SISTEM PENGOLAHAN DATA LOG QUALITY CONTROL SYSTEM PAPER MACHINE MENJADI INFORMASI PAPER PROFILE
}

\author{
Wawan Kustiawan ${ }^{1}$, Darmansyah ${ }^{2}$ \\ STMIK Rosma Karawang, Teknik Informatika \\ ${ }^{1}$ kustiawan@hotmail.com, ${ }^{2}$ trackdrs@yahoo.com
}

\begin{abstract}
QCS (Quality Control System) system that can monitor the quality of paper production in-line. The QCS system can produce paper quality data in the form of log file text. Data on the log text file can be processed and analyzed to become paper quality information with parameters consisting of: basis weight ( $\mathrm{gsm}$ ), ash titration, moisture content, porosity and opacity. The paper quality information is called paper profile information. The Processing System of QCS Paper Machine Log Data to Become Paper Profile Information is developed using prototyping methodology and Visual Basic .Net programming language. This System also uses SPC (Statistical Process Control) method and utilizes the Microsoft Excel features such as VBA programming language, statistical functions, and charting function that already familiar by computer user. The Paper profile information system will store and distribute paper profile information through a web based application to the parties concerned. So that the paper profile information can be created and distributed easily and quickly. The Paper profile information is necessary to determine the quality of products and to monitor the process capability of producing the product.
\end{abstract}

Key Word: QCS, Log File, Paper Profile, Prototyping, Statistical Process Control

\begin{abstract}
ABSTRAKSI
Sistem QCS (Quality Control System) bisa memonitor kualitas kertas secara in-line saat proses produksi. Sistem QCS dapat mengeluarkan data kualitas kertas dalam bentuk log file teks. Data pada log file teks dapat diolah dan dianalisa untuk menjadi informasi kualitas kertas dengan parameter-parameter yang terdiri dari : basis weight (gramature), ash titrasi, moisture content, opasitas dan porositas. Informasi kualitas kertas ini disebut informasi paper profile. Sistem Pengolahan Data Log QCS Menjadi Informasi Paper Profile pada penelitian ini dikembangkan dengan menggunakan metodologi prototyping dan bahasa pemrograman Visual Basic .Net. Pengolahan data pada sistem ini menggunakan metoda SPC (Statistical Process Control) dan memanfaatkan fasilitas-fasilitas yang dimiliki oleh Microsoft Excel yaitu pemrograman VBA, fungsi-fungsi statistik dan kemampuan membuat tampilan grafis yang menarik dan sudah sangat dikenal oleh pengguna komputer. Sistem informasi paper profile akan menyimpan dan mendistribusikan informasi paper profile melalui sebuah aplikasi berbasis web kepada pihak-pihak yang berkepentingan. Sehingga informasi paper profile dapat dibuat dan didistribusikan dengan mudah dan cepat . Informasi paper profile ini diperlukan untuk mengetahui kualitas produk dan untuk memonitor kapabilitas proses dalam menghasilkan produk.

Kata kunci : QCS, Log File, Paper Profile, Statistical Process Control
\end{abstract}




\section{PENDAHULUAN}

\section{Latar Belakang}

QCS (Quality Control System) merupakan suatu sistem yang ada pada mesin kertas pada sebuah perusahaan kertas. Sistem $Q C S$ ini dilengkapi dengan sensor-sensor yang dapat membaca data parameter kualitas kertas yang diproduksi. Hasil pembacaan sensor-sensor ini ditunjukan pada monitor pada saat proses produksi. Selain itu sistem QCS juga menyediakan log file text yang dapat digunakan untuk diolah lebih lanjut.

Data pada $\log$ file QCS adalah data kualitas kertas yang sangat berharga bagi suatu perusahaan untuk dapat menentukan apakah kertas yang diproduksi layak dikirim kepada pelanggan atau tidak. Selain itu data ini dapat digunakan untuk menunjukan hasil kerja operasi dari mesin kertas yang digunakan. Namun data pada log file QCS sulit untuk dibaca karena terdiri dari kode-kode yang ditempatkan pada beberapa kolom dan baris yang jumlahnya banyak sekali.

Rumusan masalah pada penelitian ini adalah "Bagaimana cara mengolah data pada log file QCS menjadi informasi paper profile secara otomatis dan dapat didistribusikan kepada yang membutuhkannya dengan cepat dan mudah".

\section{Ruang Lingkup}

Ruang lingkup dari penelitian ini adalah pengelolaan log file text yang dihasilkan oleh sistem QCS paper machine menjadi informasi paper profile dan pendistribusian informasi paper profile kepada pihak yang berkepentingan.

\section{Tujuan dan Manfaat}

Tujuan dari pembuatan Sistem Paper Profile ini adalah :

a. Menyediakan alat yang dapat menerjemahkan data log file text $Q C S$ menjadi informasi paper profile secara otomatis dengan biaya yang ekonomis.

b. Menyediakan sistem yang dapat mendistribusikan informasi paper profile dengan cepat dan mudah.
Sedangkan manfaat dari pembuatan Sistem Paper Profile ini adalah :

a. Mengurangi biaya material dan non material untuk menyediakan informasi paper profile.

b. Memberi nilai tambah kepada pelanggan dengan mengirim barang berkualitas sehingga akan meningkatkan kepuasan pelanggan dan menjaga kesinambungan bisnis.

\section{Tinjauan Pustaka}

Menurut Angga (2013), “Quality Control merupakan usaha perusahaan dari top manajemen untuk menghasilkan produk atau pelayanan yang berkualitas". Dalam Quality Control System yang ada pada mesin pembuat kertas akan menghasilkan informasi tentang kualitas kertas yang ditampilkan pada monitor. Dengan demikian maka manajemen dapat menentukan apakah kertas tersebut layak untuk diberikan kepada pelanggan atau tidak.

Penelitian yang pernah dilakukan berhubungan dengan Quality Control Systems ini adalah penelitian yang dilakukan oleh Hiroshi Fukumine dan Fumihara Miura dari Yokogawa Jepang pada tahun 2011. Hasil dari peneltian ini dituangkan dalam sebuah jurnal yang berjudul "Control Parameter Optimization Service for Paper Machine Quality Control Systems, QCS Tune-up Engineering, for Ideal Paper Manufacturing Plant".

Penelitian tersebut berisi tentang layanan rekayasa untuk melakukan tune-up terhadap parameter kontrol sistem QCS yang bertujuan untuk menurunkan angka variasi yang muncul pada proses produksi kertas sehingga dapat mengurangi biaya produksi dan meningkatkan kualitas produk. Berikut adalah perbandingan antar penelitian yang dilakukan oleh Hiroshi Fukumine dan Fumihara Miura dengan penelitian yang dilakukan oleh penulis:

Tabel 1. Perbandingan Penelitian

\begin{tabular}{|c|l|l|}
\hline Topik & $\begin{array}{l}\text { Penelitian } \\
\text { Yokogawa }\end{array}$ & \multicolumn{1}{|c|}{$\begin{array}{c}\text { Penelitian } \\
\text { Penulis }\end{array}$} \\
\hline Objek & $\begin{array}{l}\text { Parameter } \\
\text { kontrol } \\
\text { sistem QCS }\end{array}$ & $\begin{array}{l}\text { Log file sistem } \\
\text { QCS }\end{array}$ \\
\hline
\end{tabular}




\begin{tabular}{|l|l|l|}
\hline Metodologi & $\begin{array}{l}\text { Diagnosa, } \\
\text { proposal } \\
\text { solusi, } \\
\text { tuning } \\
\text { parameter, } \\
\text { training }\end{array}$ & $\begin{array}{l}\text { Survei, } \\
\text { prototyping, } \\
\text { OOP }\end{array}$ \\
\hline Hasil & $\begin{array}{l}\text { Sistem QCS } \\
\text { yang telah } \\
\text { dioptimalkan }\end{array}$ & $\begin{array}{l}\text { Aplikasi/sistem } \\
\text { paper profile }\end{array}$ \\
\hline Tujuan & $\begin{array}{l}\text { Menurunkan } \\
\text { biaya, } \\
\text { kualitas } \\
\text { produk } \\
\text { meningkat }\end{array}$ & $\begin{array}{l}\text { Menurunkan } \\
\text { biaya, kualitas } \\
\text { produk } \\
\text { meningkat, } \\
\text { kepuasan } \\
\text { pelanggan }\end{array}$ \\
\hline
\end{tabular}

\section{Metode Penelitian}

Metoda yang akan digunakan dalam penelitian ini adalah metoda pengembangan software prototyping dengan hasil akhir berupa sistem pengolah log file text QCS menjadi informasi paper profile.

\section{Hasil Penelitian dan Pembahasan}

\section{Arstitektur Solusi}

Untuk dapat memperoleh informasi paper profile dari data log file QCS maka perlu dibangun sebuah sistem yang mampu mengolah data kualitas produksi kertas yang ada pada log file QCS menjadi informasi paper profile. Sistem yang dibangun harus dapat memberi kemudahan pada pengguna dan harus dapat mendistribusikan informasi paper profile kepada semua pengguna yang membutuhkannya. Selain itu sistem yang dibangun juga harus ekonomis dan dapat dipergunakan dengan segera.

Rancang bangun solusi sistem pengolahan data log file QCS menjadi informasi paper profile ditunjukan oleh Gambar 1. Ada tiga komponen utama pada rancang bangun sistem pengolahan data log file QCS paper machine menjadi informasi paper profile sebagai berikut

1. Log Processor: sebuah aplikasi console yang berfungsi untuk menyimpan data log file QCS paper machine ke dalam basis data, mengolah data log file QCS menjadi informasi paper profile dengan memaksimalkan penggunaan fungsi-fungsi yang dimiliki oleh Microsoft Excel khsusnya kemampuan VBA, fungsi-fungsi statistik dan pembuatan grafik. Log Processor akan menghasilkan Informasi Paper Profile dalam format PDF dan menyimpannya ke dalam basis data. Log Processor akan dipicu oleh windows task scheduler untuk berjalan secara otomatis pada waktu yang ditentukan.

2. Profile Viewer : sebuah aplikasi berbasis web intranet yang berfungsi menampilkan kembali informasi paper profile yang tersimpan dalam basis data kepada pengguna yang memerlukan. Penggunaan aplikasi web memungkinkan informasi paper profile dapat terdistribusi kepada pihak-pihak yang membutuhkan dengan cepat dan bisa diakses kapan saja dibutuhkan.

3. Admin Config : sebuah aplikasi berbasis windows yang berfungsi untuk mengatur konfigurasi Log Processor, merubah master data, menambahkan data pengujian laboratorium manual, menjalankan proses pembuatan paper profile, melihat hasil pemrosesan dan melihat error-error yang terjadi pada saat pengolahan data log QCS paper machine menjadi informasi paper profile.

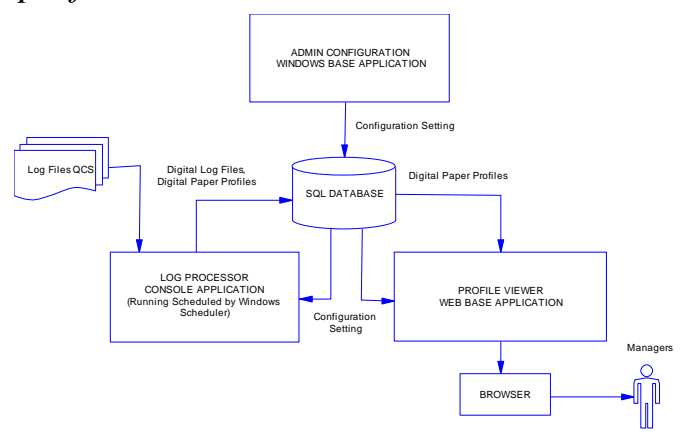

Gambar 1. Arsitektur Sistem Paper Profile

\section{Perancangan Sistem Pengolahan Data Log File QCS}

Perancangan sistem pengolahan data $\log$ file QCS menjadi informasi paper profile dilakukan menggunakan pemodelan Unified Modeling Language (UML). Pemodelan UML merupakan pemodelan yang cocok dengan pengembangan aplikasi menggunakan konsep Object Oriented Programming (OOP) karena pemodelan UML mengarah kepada 
pembentukan kelas-kelas dan objek-objek beserta relasi, interaksi dan kolaborasi diantara mereka sebagai landasan untuk pembuatan kelas-kelas dan objek-objek yang akan diimplemtasikan di dalam program.

\section{Perancangan Log Processor}

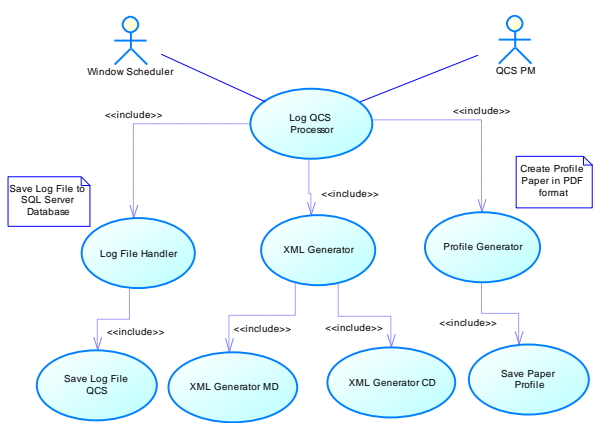

Gambar 2. Uses Case Diagrams Log Processor Use case diagrams Log QCS Processor merepresentasikan rancangan kemampuan sistem untuk mengolah log file QCS menjadi informasi paper profile. Log File Handler menunjukan kemampuan sistem untuk menangani pengelolaan file secara fisik yaitu menyimpan log file QCS ke dalam basis data. $X M L$ Generator menunjukan fungsi sistem untuk mengolah data yang ada pada log file QCS menjadi lebih terstruktur dengan mengubahnya menjadi file XML MD dan file XML CD. Sedangkan use case Profile Generator menunjukan kemampuan sistem untuk membuat file Paper Profile secara otomatis dan menyimpanannya ke dalam basis data.

\section{Class Diagrams Log Processor}

Kelas Controler adalah kelas yang akan mengendalikan jalannya pembuatan Paper Profile secara otomatis. Objek Contoler akan terbentuk dengan trigger dari Windows Task Scheduler pada waktu yang sudah dijadwalkan. Objek Controler selanjutnya akan mengatur kemunculan objek-objek lain yang ada di package PaperProfileLabPack sesuai dengan tahapan proses pembuatan Paper Profile. Package PaperProfileLabPack adalah sebuah paket kelas yang terdiri dari beberapa kelas yaitu kelas Reel, kelas Grade, kelas PaperProfile, kelas Logfile, kelas Config dan kelas LabProfile. Kelas-kelas ini nantinya akan diimplementasikan menjadi kumpulan library dalam aplikasi.

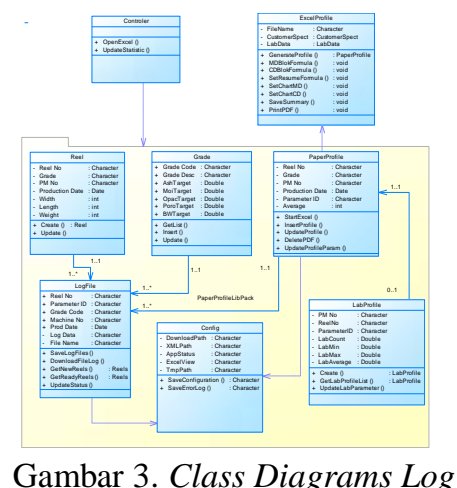

\section{Sequence Diagrams Log File Handler}

Sequence Diagrams Log FileHandler (lihat Gambar 4) memodelkan interaksi antar objek untuk menangani proses penyimpanan log file kedalam basis data. Windows task scheduler akan memicu Controler untuk mulai bekerja. Controler memeriksa status aplikasi apakah sedang "Idle" atau "Running".

Jika status aplikasi "Idle" maka Controler akan segera merubah status aplikasi menjadi "Running" dan memerintahkan objek Log File untuk menyimpan log file QCS yang ada di directory UploadPath ke dalam basis data. UploadPath merupakan properti dari objek Config yang menunjukan folder tempat log file QCS disimpan. Setelah semua log file di-upload ke dalam basis data maka log file QCS yang ada di UploadPath dihapus dan UploadPath menjadi kosong.

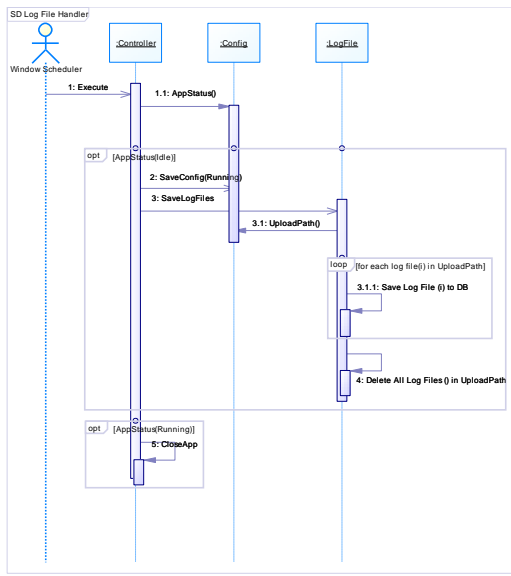

Gambar 4. Sequence Diagrams Log File Handler 


\section{Sequence Diagrams XML Generator}

Sequence diagrams XML Generator memodelkan interaksi objek-objek pada saat pembentukan file XML yang akan digunakan sebagai sumber data oleh Excel untuk membuat Paper Profile.

Ada 2 macam file $X M L$ yang terbentuk yaitu file XML CD (Cross Direction) dan file XML MD (Machine Direction). Format file XML dipilih untuk digunakan oleh Excel karena file XML terstruktur dan mudah dikelola dengan menggunakan Excel dimana Excel sendiri telah memiliki kemampuan untuk membaca file XML dan memperlakukannya sebagai sebuah tabel data.

Setelah proses penyimpanan log file $Q C S$ ke basis data selesai, Controler memerintahkan $X M L$ Generator untuk bekerja. File log QCS akan diambil terlebih dahulu dari basis data dan disimpan di folder DownloadPath oleh objek Log File. DownloadPath merupakan salah satu properti dari objek Config.

Controler mengirim data Customer Spect dan Lab Data kedalam Excel Paper Profile. Selanjutnya Controler mengirim pesan kepada Excel Paper Profile untuk menjalankan suatu program VBA.

Dengan program VBA ini Excel melakukan proses analisa dan pengolahan data XML serta membuat informasi Paper Profile. Excel Paper Profile akan menghasilkan informasi Paper Profile berupa file dalam format PDF yang berisi control chart kualitas paper roll per parameter test berikut informasi customer specification dan summary analisa statistik terhadap data yang diberikan.

Selanjutnya Controler

akan memerintahkan Profile Generator untuk melakukan penyimpanan file Paper Profile ke dalam basis data. Setelah file Paper Profile disimpan ke dalam basis data kemudian propertiproperti yang menyimpan nilai-nilai agregasi pada record data paper profile dalam basis data di-update sesuai dengan hasil analisa data pada Excel Paper Profile oleh Controler.

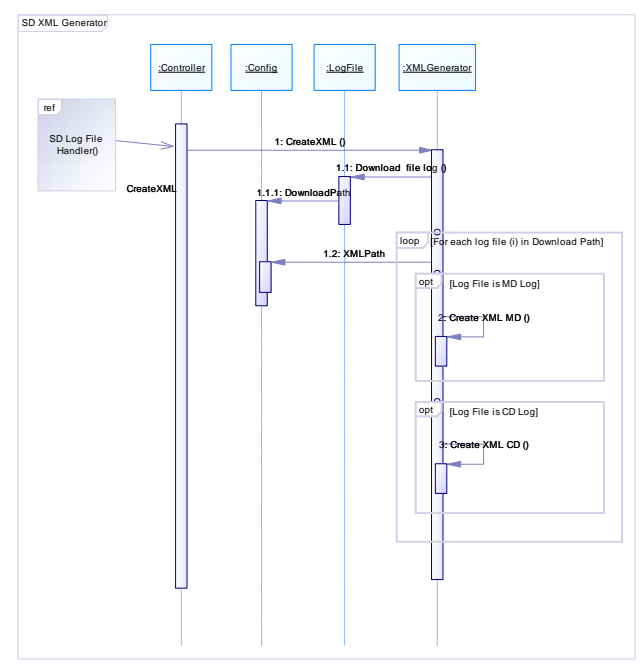

Gambar 5. Sequence Diagrams XML Generator

\section{State Chart Diagrams Log Processor}

Pada saat Log Processor mendapat trigger dari Windows Task Scheduler harus berada dalam status "Idle" agar proses pengolahan log file bisa dijalankan. Jika status "Idle" maka log processor akan segera beroperasi untuk menyimpan log file QCS yang ada ke dalam basis data dan mengubah status proses menjadi "Save Log File". Setelah log file berhasil disimpan status log processor akan berubah menjadi "Download Log File", ini menandakan bahwa log processor sedang melakukan penyimpanan log file kedalam folder DownloadPath. Setelah itu $\log$ file yang ada di folder DownloadPath akan diolah menjadi XML file dan status Log Processor akan berubah menjadi "Create XML". Selanjutnya Log Processor akan membuka aplikasi Excel dan mengontrol file Excel untuk menganalisa data dengan perhitungan statistik, membuat control chart dan membentuk file PDF Paper Profile. Pada kondisi ini Log Processor akan berstatus "Generate Profile".

Setelah Paper Profile berhasil dibuat maka Log Processor akan menyimpan Paper Profile ke dalam basis data dan statusnya akan berubah menjadi "Save Paper Profile". Setelah semua proses selasai maka status Log Processor akan kembali menjadi "Idle".

Apabila terjadi kesalahan atau error kapan saja selama proses pengolahan log file maka status 
Log Processor akan berubah menjadi "Error" dan error yang terjadi akan dicatat kedalam error $\log$.

\section{Implementasi}

Rancangan sistem yang telah dibuat selanjutnya akan diimplementasikan dengan menggunakan bahasa pemrograman Visual Basic .Net 2008. Sistem paper profile ini akan diimplementasikan menjadi 6 buah komponen sistem 2008 sebagai berikut :

1. Project PaperProfileLib adalah project Visual Studio bertipe Class Library. Project ini berisi kelas-kelas yang akan menjadi referensi library untuk project lain dalam sistem ini dalam bentuk file dan lain-lain. Diantara kelas itu ada yang dinamakan Kelas Profile Generator yaitu kelas yang akan melakukan proses otomasi antara program visual studio .net dengan file Excel PaperProfile.xlms untuk membuat informasi paper profile.

2. Project LogProcessor adalah sebuah console application Project yang akan mengendalikan kelas-kelas library yang sudah dibuat pada project PaperProfileLib. Pengendalian terhadap kelas-kelas library untuk mengolah data log QCS menjadi informasi paper profile dilakukan oleh satu module pada project ini yaitu module controller. Pengendalian terhadap kelaskelas library untuk mengolah data $\log$ QCS menjadi informasi paper profile dilakukan oleh satu module pada project ini yaitu module controller. Module Controler memiliki referensi ke kelas-kelas yang dibuat pada Project PaperProfileLib. objConfig adalah referensi ke kelas SetConfig, objLog adalah referensi ke kelas LogFile, objProfile adalah referensi ke kelas PaperProfile dan objXML adalah referensi ke kelas XMLGenerator. Proses pengolahan data $\log$ QCS sehingga menjadi informasi paper profile dilakukan oleh sebuah file excel yang dilengkapi dengan dengan program VBA untuk membuat fungsi-fungsi statistik pada cell-cell work sheet secara dinamis sesuai dengan parameter test kualitas produk yang sedang dihitung. Module VBA pada file
Excel PaperProfile berisi program-program untuk mengolah data kualtitas produk yang diperoleh dari log file QCS

3. Project AdminConfig adalah projek aplikasi berbasis Windows Forms disini memiliki 5 (lima) form. Dalam project ini dilakukan proses pengolahan log file QCS menjadi Paper Profile oleh aplikasi Log Processor, melakukan entry maupun update data grade quality control yaitu data target, nilai batas atas dan nilai batas bawah setiap parameter kualitas oleh Tab Grade QC, Tab Lab Data, tab ini digunakan untuk meng-entry data hasil tes laboratorium. Tab Manual Process, tab ini digunakan untuk melakukan process pengolahan $\log$ file QCS melalui form frmAdmin, Tab Profile List, tab ini digunakan untuk menampilkan list PaperProfile yang sudah ada di basis data, Error Log , tab ini digunakan untuk menampilkan error-error yang terjadi pada saat pegolahan data oleh sistem.

4. Project WebPaperProfile adalah web base project yang digunakan untuk menampilkan paper profile hasil dari pengolahan data $\log$ file QCS.

5. File Excel PaperProfile

6. Sebuah Basis data SQL Server yang diberi nama Utilities.

\section{KESIMPULAN DAN SARAN}

\section{Kesimpulan}

Setelah menyelesaikan penelitian dan melakukan implementasi dari penelitian ini penulis dapat menarik kesimpulan sebagai berikut :

a. Sistem Paper Profile dapat membantu pengguna untuk mengungkap data kualitas produk yang terkandung pada log file QCS dengan mudah dan cepat.

b. Sistem Paper Profile dapat membantu mengetahui kualitas produk kertas per parameter kualitas baik ke arah Cross Direction maupun ke arah Machine Direction secara in-line. 
c. Sistem Paper Profile dapat mendistribusikan informasi Paper Profile kepada pihak-pihak yang berkepentingan yaitu bagian Quality Control dan bagian Produksi secara mudah dan cepat.

d. Sistem Paper Profile dapat digunakan untuk membantu mengetahui kapabilitas proses mesin kertas.

e. Informasi yang dihasilkan oleh Sistem Paper Profile dapat mendukung pembuatan kertas dengan kualitas yang sesuai dengan kebutuhan pelanggan secara konsisten sehingga bisa menjadikan kepuasan pelanggan dan menjaga kesinambungan bisnis.

\section{Saran}

Saran-saran yang dapat penulis sampaikan untuk pengembangan sistem paper profile ini adalah sebagai berikut :

a. Informasi hasil pengujian dari laboratorium disarankan dapat ditarik secara otomatis dari sistem basis data kualitas kedalam laporan paper profile untuk dijadikan pembanding terhadap summary paper profile.

b. Pertambahan data pada basis data tempat menyimpan data $\log$ file QCS dan data file PDF Paper Profile akan berkembang menjadi sangat besar sehingga disarankan untuk menggunakan sistem basis data yang mendukung untuk pengolahan data yang sangat besar (big data) dan in memory computing.

c. Sistem Paper Profile ini dapat dikembangkan menjadi Sistem Data Mining dengan Sistem Kecerdasan Buatan (Artificial Intelligence) yang sesunguhnya untuk menjadi suatu sistem pakar tentang penentuan kualitas kertas hasil produksi sebuah mesin pembuat kertas.

\section{Daftar Pustaka}

Angga, W. (2013, July 11). Dasar-dasar Quality Control. Retrieved February 20, 2015, from IPQI (Indonesia Productivity And Quality Institute) website: http://ipqi.org/sekilas-tentangdasar-dasar-quality-control/

Fukumine, Hirosi and Miura, Fumiharu. 2010. Control Parameter Optimization Service for Paper Machine Quality Control Systems, QCS Tune-up Engineering, for Ideal Paper Manufacturing Plant. Yokogawa Technical Report English Edition Vol.54 No.1. : Japan.

Omar, M. Hafidz. 2010. Statistical Process Control Charts for Measuringand Monitoring Temporal Consistency of Ratings. Journal of Educational Measurement Spring Vol. 47 No.1. King Fahd University of Petroleum And Mineral: Saudi Arabia.

Mahesh, B.P. and Prabhuswamy, M.S. 2010. Process Variability Reduction Through Statistical Process Control for Quality Improvement. International Journal for Quality research UDK-005.6.642.2 Short Scientific Paper (1.03) Vol. 4 No 3. India.

Bosch, Robert GmbH. 2004. Machine and Process Capability. Quality Management in the Bosch Group - Technical Statistics. Bosch : Germany.

Najjar, L. J. 1990. Rapid prototyping (TR 52.0020). Atlanta, GA: IBM Corporation :USA

Sommerville, Ian. 2000. Software Engineering $6^{\text {th }}$ Edition.USA

Pelland, Patrice. Microsoft Visual Basic 2008 Express Edition. Microsoft Press : USA

DeBetta,Peter and Law, Greg and Whitehorn, Mark. 2008. Introducing to Microsoft SQL Server 2008. Microsoft Press. USA

Fitzgerald, Jerry. 1987. Fundamental of Anaysis : Using Structured And Design Techniques. John Willey \& Son : Singapore.

Yourdon, Edward. 1989. Modern Structured Analysis. Printice Hall : USA.

Tim Litbang Wahana Komputer. 2013. Pemrogrman VBA dengan Excel 2013. Penerbit Andi : Yogyakarta

Miller, Randy. Practical UML : A Hand-on Introduction for Developers. http://edn.embarcadero.com/article/3186 3. Tanggal akses : 09-03-2 